Lister's instructions and could not replicate his results. The eminent surgeon James Paget's 1869 declaration in The Lancet that Lister's system was "no good" was damning.

However, Lister's reputation in Britain was ultimately sealed by one high-profile patient: Queen Victoria. By 1871, he was the most renowned surgeon in Scotland, and successfully treated his royal patient for a large underarm abscess at Balmoral Castle. In 1876, Lister demonstrated his technique at the International Medical Congress in Philadelphia, Pennsylvania, convincing many US sceptics. Massachusetts General Hospital, which had banned his methods for years, became the first US hospital to endorse their use.

Lister received numerous honours and awards: a peerage, the Order of Merit and presidency of the Royal Society. Moreover, Britain began to obsess over cleanliness. The flourishing commercial companies of the late nineteenth century rushed to make products to satisfy the trend, including carbolic smoke balls (for nasal inhalation, to flush out infections), fumigators, soaps and the enduring oral antiseptic Listerine. Lister's place in the history of surgery was assured. Widespread adoption of his techniques exemplified the acceptance of germ theory; in time, there was a shift from antisepsis (germ-killing) to asepsis (germ-free). Ironically, as Fitzharris reveals, Lister resisted this: he believed that asepsis would be impossible in the home, where the wealthy and middle classes were treated. He failed to realize that he had sown the seeds for the rise of the hospital as a place for the specialist care of all, not just the poor.

The Butchering Art is well researched and written with verve. Fitzharris takes some licence with speculative conversations, thoughts and emotions, and a few anachronisms irk. For example, University College (called the modern 'UCL' throughout) did not have a 'campus'; neither did nineteenthcentury physicians see non-hospital patients in their 'offices'. Nevertheless, this is a fine read full of vivid detail, prompting thoughtful reflection on the past, and the challenging future, of surgical practice.

Tilli Tansey is emeritus professor of medical history and pharmacology at Barts and The London, Queen Mary University of London. e-mail:t.tansey@qmul.ac.uk

\title{
SUSTAINABILITY
}

\section{China's path to ecotopia}

\author{
Xuemei Bai critiques a critique of the country's \\ eco-city initiative.
}

I t's easy to get a sense of China's rapid urbanization: overwhelming numbers and breathtaking images abound. In 40 years, the country's urban population has quadrupled to about 800 million, and its cities have tripled in number, to 657 . To seek urban development with better economic, environmental and social outcomes, China has introduced many branding and accrediting schemes.

One is the eco-city. By 2016, at least 220 cities, towns, prefectures and districts had received the national accreditation for their socio-economically beneficial and ecologically 'clean' features such as renewable energy and water recycling. There is so much information on China's urban mosaic that it's hard to make sense of it.

In China's Urban Revolution, architect and writer Austin Williams attempts to do so, probing the country's eco-city experiment against the background of its socioeconomic realities. The speed of change in China makes it extremely challenging to grasp what is happen-

ing and why: the social and political context can lose relevance rapidly, and so become risky to reference in as little as a decade. Williams should be commended for trying. He promises a nuanced view that is neither sinocentric nor biased towards the West - enticing for those who seek insights beyond blind criticism or blind optimism.

Unfortunately, the book falls short of this promise. Williams asserts that it is a "political assessment" of China's eco-urban initiatives, and that his exploration may "give rise to a number of contradictory viewpoints".

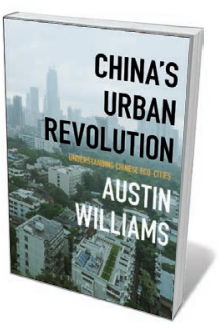

China's Urban Revolution: Understanding Chinese Eco-Cities AUSTIN WILLIAMS

Bloomsbury Academic: 2017.

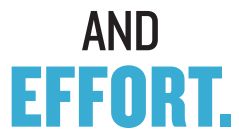

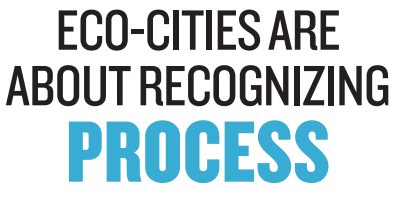

China Several high-profileplanned eco-cities, such as Dongtan near Shanghai, are still unbuilt; projects can end up as box-ticking; development may take priority over sustainability. However, Williams often interprets local malpractices or failures as pertaining to China as a whole, and links them to perceived underlying politics. What I miss is a serious critique on why projects fail, and what can be learnt. The book bolts anecdotes and fragmented (but valuable) facts into sweeping political or ideological conclusions, often without in-depth analysis.

Williams looks at Chinese eco-cities and their contexts through the lens of Western environmental thinking. He compares progressive Western scholarship on sustainability (such as biologist Rachel Carson's work in the 1960s) with mainstream practice in China at the time, and frames it as the West vs China. In truth, disparities between theory and practice

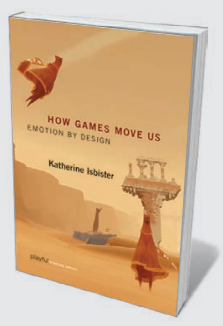

How Games Move Us: Emotion by Design Katherine Isbister (MIT Press, 2017) Games researcher Katherine Isbister offers fascinating insights into the ways in which designers trigger players' emotions. The ability to customize characters' appearance and personality in The Sims, for example, encourages players to form virtual attachments to the avatar.

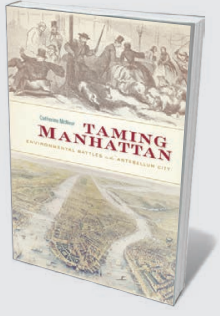

Taming Manhattan

Catherine McNeur (Harvard Univ. Press, 2017) Before the American Civil War, Manhattan was awash in manure and sewage, and teeming with wild dogs. Catherine McNeur's absorbing history traces how New York City was tamed through urban planning, yet plagued afterwards by social tensions and environmental pressures. 
are seen in many countries. It seems, too, that whatever China is doing, there is a Western thought leader whom Williams indicates must be an influence. This is fatiguing. It is not difficult to find as many arguments in China claiming that most of today's progressive environmental ideas are rooted in ancient Chinese philosophy.

At one point, Williams misinterprets the technical and cultural practices in Chinese calligraphy and poetry to make the shaky assertion that China has no concept of copyright. Further, he claims that China has been "nicking ideas from the West to fuel its own awakening" for the past four decades, although he adds that this is "no bad thing". By contrast, he depicts Western nations as authentic, confident and with "a generally accepted narrative about their own societies over time".

If Williams's criticisms are based on innocent misinterpretation, there are two likely reasons alongside the dizzying pace of change. First, the fine print around China's eco-cities can be lost in translation. The country's accrediting team clearly states that it includes cities, towns, districts and development zones, often all translated as eco-cities. Second, demonstration projects are common, to allow others to learn from front runners. Thus, eco-cities are more about recognizing process and effort than the end stage.

Williams concludes with a discussion of China's efforts in renewable-energy development, innovation and other relevant areas, and lists the country's top eco-cities - which are mentioned rarely, if at all, in earlier chapters. He even warns against Western bias when interpreting Chinese issues. I was left wondering whether the book's shifts in tone and perspective were the result of Williams's views evolving.

China's Urban Revolution is ultimately - as a collection of "contradictory viewpoints" - unsatisfying. But many of the facts presented are fascinating.

Xuemei Bai is an adjunct professor at Beijing Normal University, and a professor in the urban environment and human ecology at the Australian National University in Canberra.

e-mail:xuemei.bai@anu.edu.au

\section{ORNITHOLOGY}

All eyes on the
10,000 species

Stuart Pimm considers the obsessive, sometimes dark side to the joyous pursuit of watching birds.

$\mathrm{W}$ hen the ship Victoria, the last remnant of Ferdinand Magellan's round-the-world voyage, returned to Seville in 1522, just 18 men survived from an expedition crew of more than 200. Magellan was not among them. Victoria held a fortune in spices - and the feathers of birds of paradise. The specimens' feet and wings had been removed, so people thought that the birds moved by divine means. Their shimmering plumage inspired wonder that galvanized both ornithologists and hunters.

Magellan's voyage, recounted in Bernd Brunner's Birdmania, is one manifestation among multitudes of humanity's great obsession with birds. By the end of 2016, one-third of a million people had contributed more than one-third of a billion observations to eBird (http://ebird.org), the world's largest citizenscience project. We know the natural history and distribution of birds much better than those of any other group. And colourful people walk the paths to this knowledge, as is amply shown in both Birdmania and Noah Strycker's Birding Without Borders. On a hike in Colombia, I contemplated these books - and concluded that I must write about passions for birds that have dark, even fatal, undercurrents.

In Brunner's tour of bird devotees through history, we meet a cast including thirteenth-century Holy Roman Emperor Friedrich II von Hohenstaufen, who authored a treatise on falconry, and twentieth-century US ornithologist Robert Porter Allen, who did much to protect the whooping crane (Grus americana). Brunner reveals how hummingbirds were admired by European travellers long before becoming a highlight of Victorian specimen cabinets. Although most species of these acrobatic wonders live in the remote Andes and Amazon, the drive to find new ones was intense. Only 34 were known by 1788 , but by 1900 , taxonomists had described 312 of the current 336. Avid collector John Gould recorded most of them in his lavishly illustrated Monograph of the Trochilidae, or Family of Hummingbirds (1849-61). The ranges of some hummingbirds are still being uncovered.

The end of this golden age of discovery was marked by a controversial figure: Richard Meinertzhagen, chair of the British Ornithologists' Club. A career army officer, he participated in military exploits such as Edmund Allenby's 1917 victory in the Middle East. He was also an explorer, touring Afghanistan in 1937 with a young Salim Ali, destined to become India's most distinguished ornithologist. There, Meinertzhagen described a new species of snowfinch (Montifringilla

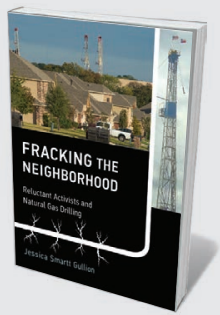

Fracking the Neighborhood: Reluctant Activists and Natural Gas Drilling Jessica Smartt Gullion (MIT Press, 2017) North Texas takes centre stage in sociologist Jessica Smartt Gullion's study of urban US fracking. She explores the state's drilling culture and industrial health risks, and interviews locals forced to cope with fracking on their doorstep.

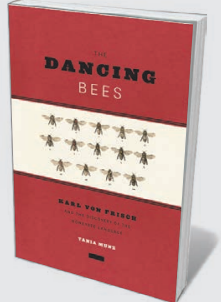

The Dancing Bees

Tania Munz (Univ. Chicago Press, 2017) In this compelling account of the work of Karl von Frisch, Tania Munz shows how, despite pressures from the Nazis, he advanced studies of animal communication. Notably, he discovered how bees 'waggle dance' to indicate food sources (see Mark L. Winston's review: Nature 533, 32-33; 2016). 